Pharmacol Ther. 2008 July ; 119(1): 96-103. doi:10.1016/j.pharmthera.2008.05.002.

\title{
Inflammation in the Vascular Bed:
}

\section{Importance of Vitamin C}

\author{
Rene Aguirre and James M. May* \\ Department of Medicine, Vanderbilt University School of Medicine, Nashville, TN 37232-6303
}

\begin{abstract}
Despite decreases in atherosclerotic coronary vascular disease over the last several decades, atherosclerosis remains a major cause of mortality in developed nations. One possible contributor to this residual risk is oxidant stress, which is generated by the inflammatory response of atherosclerosis. Although there is a wealth of in vitro, cellular, and animal data supporting a protective role for antioxidant vitamins and nutrients in the atherosclerotic process, the best clinical trials have been negative. This may be due to the fact that antioxidant therapies are applied "too little and too late." This review considers the role of vitamin C, or ascorbic acid in preventing the earliest inflammatory changes in atherosclerosis. It focuses on the three major vascular cell types involved in atherosclerosis: endothelial cells, vascular smooth muscle cells, and macrophages. Ascorbate chemistry, recycling, and function are described for these cell types, with emphasis on whether and how the vitamin might affect the inflammatory process. For endothelial cells, ascorbate helps to prevent endothelial dysfunction, stimulates type IV collagen synthesis, and enhances cell proliferation. For vascular smooth muscle cells, ascorbate inhibits dedifferentiation, recruitment, and proliferation in areas of vascular damage. For macrophages, ascorbate decreases oxidant stress related to their activation, decreases uptake and degradation of oxidized LDL in some studies, and enhances several aspects of their function. Although further studies of ascorbate function in these cell types and in novel animal models are needed, available evidence generally supports a salutary role for this vitamin in ameliorating the earliest stages of atherosclerosis.
\end{abstract}

\section{Keywords}

Atherosclerosis; antioxidant vitamins; endothelial cells; vascular smooth muscle cells; macrophages; vitamin $\mathrm{E}$

\section{Introduction: Atherosclerosis and vitamin C}

Atherosclerotic cardiovascular disease, especially when considered with associated diseases such as diabetes and hypertension, remains the number one killer of both men and women in the United States ( MRC/BHF study, 2005). Whereas the results of numerous clinical trials have definitively shown that lowering cholesterol in low density lipoprotein (LDL) delays the onset and slows the progression of atherosclerosis (LaRosa et al., 1999), its continued high prevalence indicates that additional approaches are needed to combat this disease. One area of

\footnotetext{
*Corresponding author: 7465 Medical Research Building IV, Vanderbilt University School of Medicine, 2213 Garland Ave., Nashville, TN 37232-0475. Tel. (615) 936-1653; Fax: (615) 936-1667. E-mail: james.may@ vanderbilt.edu

Publisher's Disclaimer: This is a PDF file of an unedited manuscript that has been accepted for publication. As a service to our customers we are providing this early version of the manuscript. The manuscript will undergo copyediting, typesetting, and review of the resulting proof before it is published in its final citable form. Please note that during the production process errors may be discovered which could affect the content, and all legal disclaimers that apply to the journal pertain.
} 
increasing interest is that oxidant stress contributes to atherosclerosis. This stems from the hypothesis that oxidized LDL accelerates atherosclerosis (Witztum \& Steinberg, 2001), a concept supported by both tissue culture and animal studies (Berliner \& Heinecke, 1996). Nonetheless, several clinical trials testing whether atherosclerosis is slowed by supplements of vitamins $\mathrm{C}$ and $\mathrm{E}$, alone or in combination, have been for the most part negative (2002). However, these trials may not have targeted the right group (only secondary prevention in advanced atherosclerotic disease was studied) (Blumberg \& Frei, 2007), or may not have used adequate amounts of vitamin supplements (Roberts et al., 2007). Moreover, accumulating in vitro and animal data continue to support a role for both vitamins, and especially for vitamin $\mathrm{C}$, in countering multiple steps in the atherosclerotic process. In a commentary on this dichotomy, the Nutrition committee of the American Heart Association stated: "we recommend that antioxidant research continue in order to resolve whether the oxidative modification hypothesis is relevant to human atherosclerosis" (Kris-Etherton et al., 2004). This review deals with the potential role of vitamin $\mathrm{C}$, or ascorbic acid, to prevent the early stages of atherosclerosis.

Atherosclerosis is now considered to be an inflammatory disease of the blood vessel wall, characterized in early stages by endothelial dysfunction, recruitment and activation of monocyte/macrophages, and dedifferentiation and migration of vascular smooth muscle cells (VSMCs) to later form the bulk of the atherosclerotic plaque (Hansson, 2005; Ross, 1999). Whereas inflammation may initiate the disease, it is likely that the resulting oxidative stress propagates it and worsens injury (Stocker \& Keaney, Jr., 2004). It is plausible that antioxidants such as ascorbate might mitigate the earliest stages of inflammatory atherosclerosis, but have lesser effects on established lesions. Table 1 summarizes the evidence to be discussed in this review that ascorbate modifies these early steps in atherosclerosis, although not necessarily through its antioxidant actions.

These effects of ascorbate may explain the observations of Willis over 50 years ago that both acute and chronic scurvy in guinea pigs produced intimal lesions indistinguishable from those of human atherosclerosis (Willis, 1953), and that such lesions were reversed by ascorbate supplements (Willis, 1957). Indeed, atherosclerosis has been termed a disease of "latent" scurvy (Price et al., 1996). In this regard, it is intriguing to note that humans and guinea pigs (both unable to synthesize ascorbate) are the only mammals known to develop spontaneous atherosclerosis without dietary cholesterol feeding (Price et al., 1996).

\section{Ascorbate dietary requirements and function}

Although most mammals are capable of synthesizing ascorbate endogenously, during evolution humans lost the capacity to produce the vitamin. This is due to an inactivating mutation of Lgulono- $\gamma$-lactone oxidase (EC 1.1.3.8), which occurred approximately 40 million years ago (Nishikimi et al., 1994). Absorption of vitamin C occurs primarily in the distal small intestine via active transport through an ascorbate transporter termed the Sodium-dependent Vitamin C Transporter- type 1 (SVCT1, gene product of slc23al) (Tsukaguchi et al., 1999). This transporter is also present in the renal proximal tubules (Tsukaguchi et al., 1999), where it serves to reabsorb filtered ascorbate. Ascorbate circulates in blood at 30-60 $\mu \mathrm{M}$, but its concentrations in most cells are considerably higher. This is due to its active transport by another ascorbate transporter isoform, termed the SVCT2 (gene product of slc23a2)

(Tsukaguchi et al., 1999). The SVCT2 is present in most tissues in the body, including brain, lung, liver, and cardiac and skeletal muscle (Tsukaguchi et al., 1999). Plasma concentrations of ascorbate are limited to about $120 \mu \mathrm{M}$ due to saturation of absorption, uptake into tissues, and failure of complete reabsorption in the kidney. The current recommended dietary daily allowances for vitamin $\mathrm{C}$ are $90 \mathrm{mg}$ for men and $75 \mathrm{mg}$ for women. At intakes of the vitamin above about $60 \mathrm{mg} / \mathrm{d}$ in both genders, ascorbate begins to appear in the urine (Levine et al., 
2001). However, intakes of $250 \mathrm{mg} / \mathrm{d}$ and higher are required to saturate ascorbate concentrations in plasma and contents of white blood cells (Levine et al., 2001). Although there are clear limits on the amounts of vitamin $\mathrm{C}$ that humans can retain, the current dietary recommendations do not provide tissue-saturating ascorbate concentrations.

Ascorbate contributes to many important enzyme reactions, including those leading to the synthesis of norepinephrine, carnitine, cholesterol, amino acids, and several peptide hormones (Chatterjee et al., 1975). In many of these processes, ascorbate serves as a co-factor and electron donor in reactions catalyzed by dioxygenase enzymes (Arrigoni \& De Tullio, 2002). Perhaps best known of these are the prolyl and lysyl hydroxylases that catalyze hydroxylation of hypoxia-inducible factor-1 $\alpha$ (Bruick \& McKnight, 2001) and procollagen (Myllylä et al., 1984). Given the clinical manifestations of scurvy (hemorrhage, loss of teeth, tendon rupture), stabilization of collagen by ascorbate certainly seems to be critical to forming the connective tissue framework of the entire body; including skin, bones, cartilage, tendons, ligaments, and blood vessels. However, its antioxidant properties have stimulated most recent interest in its diverse functions, with interest focused on protection of cells and tissues from damage due to radical species generated by acute or chronic inflammation and metabolic byproducts.

Ascorbate is a primary antioxidant in that it directly neutralizes radical species. Ascorbate is not very reactive with prevalent cellular oxidants such as hydrogen peroxide and probably reacts mostly with hydrogen peroxide breakdown products (Buettner \& Jurkiewicz, 1996). Whereas ascorbate may scavenge such oxidants, it can also donate electrons directly to free ferric and cupric ions, which will actually increase their redox cycling and generation of reactive oxygen species (Buettner \& Jurkiewicz, 1996; Halliwell, 1999). This could be a significant problem in areas involved in inflammation or atherosclerosis, where free transition metals may be available due to tissue disruption (Stocker \& Keaney, Jr., 2005). Within the cell, the major radical byproduct of mitochondrial oxygen metabolism is superoxide. Although ascorbate concentrations of $100 \mu \mathrm{M}$ and higher are required to appreciably scavenge superoxide (Jackson et al., 1998), as discussed below, ascorbate concentrations in nucleated cells are typically in the low millimolar range. Whereas ascorbate can act as a pro-oxidant, its relatively high intracellular concentrations, coupled with redundant mechanisms for its regeneration, appear on the whole to protect DNA, protein and lipid from oxidant damage (Carr \& Frei, 1999).

Ascorbate can also recycle vitamin E, or $\alpha$-tocopherol, from its radical form (Niki et al., 1995). The importance of ascorbate recycling of $\alpha$-tocopherol stems from properties of the latter as a lipophilic antioxidant, capable of interfering with atherogenic oxidative modification of LDL (Esterbauer et al., 1990; Thomas \& Stocker, 2000). Even though the tocopheroxyl radical is embedded in the LDL micelle or membrane bilayer, it is accessible to ascorbate in the aqueous phase for reduction (Buettner, 1993). This cooperative relationship has been shown to significantly decrease copper mediated LDL oxidation in vitro (Berliner \& Heinecke, 1996; Esterbauer et al., 1990), down regulate expression of endothelial VEGF (Nespereira et al., 2003; Rodriguez et al., 2005), and decrease production of reactive oxygen species though down regulation of vascular NADPH oxidase (Chen et al., 2001). While there is ample in vitro evidence that ascorbate spares $\alpha$-tocopherol in plasma LDL (Frei et al., 1989; Niki et al., 1995), results are mixed as to whether ascorbate protects it in cells. Glascott and co-workers (Glascott, Jr. et al., 1996) found that there was no sparing of $\alpha$-tocopherol by ascorbate in hepatocytes exposed to an oxidant stress generated by allyl alcohol. On the other hand, subsequent studies in diverse cell types showed that ascorbate prevented $\alpha$-tocopherol loss due to milder oxidant stresses in erythrocytes (May et al., 1998b), hepatocytes (Huang \& May, 2003), and neuronal cells ( $\mathrm{Li}$ et al., 2003) In endothelial cells, ascorbate prevented atherogenic modification of mildly oxidized LDL (Martin \& Frei, 1997) and preserved $\alpha$-tocopherol in both cells and LDL (Sabharwal \& May, 2008). Despite results of in vitro studies, until recently 
it had not been demonstrated that ascorbate spares $\alpha$-tocopherol in either animals or humans under oxidant stress. This problem was dispelled with the study by Traber's group (Bruno et al., 2006), which was carried out in otherwise healthy smokers. Many persons who smoke have low levels of plasma and cellular ascorbate (Lykkesfeldt et al., 2000; Schectman et al., 1989), as well as increased fractional disappearance rates of $\alpha$-tocopherol (Bruno et al., 2005). The study by Bruno, et al. was a double-blind, placebo-controlled, cross-over trial in 11 smokers and 10 non-smokers. Ascorbate supplements of $500 \mathrm{mg}$ twice daily for two weeks were sufficient to normalize the fractional disappearance rate of $\alpha$-tocopherol in the smokers (Bruno et al., 2006). The ability of ascorbate to serve as a co-antioxidant to help preserve $\alpha$-tocopherol thus provides another mechanism by which it could lessen the oxidative damage associated with early atherosclerosis.

\section{Ascorbate chemistry, cell uptake and ascorbate recycling in vascular cells}

\subsection{Ascorbate Chemistry}

Ascorbate is an antioxidant because of the shared ability of the hydroxyl groups on carbons- 2 and -3 to donate a hydrogen atom (both an electron and a proton) to a variety of oxidants, including oxygen- and nitrogen-based free radicals, peroxides and superoxide (Buettner, 1993). Ascorbate oxidation is reversible, which allows for recycling from its oxidized forms (Fig. 1). Ascorbate is a one-electron donor in both scavenging radical species and in reducing ferric iron in dioxygenase enzymes. The one-electron oxidized form of ascorbate, commonly termed the ascorbate free radical (AFR), is surprisingly stable and can be detected at $10 \mathrm{nM}$ concentrations in biological fluids by electron paramagnetic resonance spectroscopy (Buettner \& Jurkiewicz, 1993; Coassin et al., 1991; Mehlhorn, 1991). Instead of undergoing further oxidation, two molecules of the AFR are thought to react and dismutate to form ascorbate and dehydroascorbate (DHA) (Fig. 1) (Bielski et al., 1975). DHA is unstable at physiologic pH, with a half-life of about 6 min (Drake et al., 1942; Winkler, 1987). With hydrolysis of the lactone ring, it is irreversibly converted to 2,3-diketo-1-gulonic acid (Fig. 1) (Bode et al., 1990; Chatterjee, 1970). Ascorbate loss due to ring-opening of DHA is wasteful of the vitamin, and cells have developed redundant mechanisms to recycle DHA back to ascorbate.

\subsection{Cellular uptake of ascorbate}

As in most nucleated cell types, cultured endothelial cells (Ek et al., 1995; May et al., 2003b), vascular smooth muscle cells (Holmes et al., 2000; Voskoboinik et al., 1998), and macrophages (May et al., 2005b; May et al., 2005a) take up and concentrate ascorbate against a gradient. At high physiologic ascorbate concentrations, these cells can concentrate ascorbate from 2-50-fold in culture. Ascorbate transport in these and other cells has characteristics of the SVCT: it is of relatively high affinity $\left(\mathrm{K}_{\mathrm{m}}=20-80 \mu \mathrm{M}\right)$ and depends on the $\mathrm{Na}^{+}$gradient across the cell membrane to allow accumulation of ascorbate against a concentration gradient (Rose, 1988; Tsukaguchi et al., 1999). Such concentrative uptake generates intracellular ascorbate concentrations of 4-6 mM in human neutrophils and monocytes (Bergsten et al., 1990). Although intracellular ascorbate concentrations have not been measured in freshly isolated endothelial or smooth muscle cells, their capacity to concentrate ascorbate in culture suggests that in vivo intracellular ascorbate concentrations are in the low millimolar range. For example, human-derived umbilical vein endothelial cells take up ascorbate from the medium to reach intracellular concentrations of 3-4 mM (Martin \& Frei, 1997; May \& Qu, 2005), and require such concentrations for optimal synthesis of type IV collagen (May \& Qu, 2005). Endothelial cells derived from both pigs (Best et al., 2005) and mice (Qiao \& May, 2008) have been shown to express the SVCT2 in culture. Freshly isolated mouse peritoneal macrophages contain ascorbate concentrations of about $3 \mathrm{mM}$ and also express the SVCT2 (May et al., 2005b). 
In addition to high affinity ascorbate uptake, virtually all mammalian cells can take up DHA by facilitated diffusion on the ubiquitous GLUT-type glucose transporter. Once inside the cells, DHA is rapidly reduced to ascorbate. Nevertheless, it is unlikely that DHA uptake and reduction contributes much to intracellular ascorbate concentrations. Thus, DHA must compete with Dglucose for uptake on the GLUT-type transporters. Since plasma D-glucose concentrations are $5 \mathrm{mM}$ and those of DHA are less than $2 \mu \mathrm{M}$ (Dhariwal et al., 1991), DHA uptake will not be favored in cells in the vascular bed. Further, human erythrocytes, which contain abundant GLUT1 (Allard \& Lienhard, 1985), but no SVCT2 (May et al., 2007), have intracellular ascorbate concentrations very close to those in the blood from which they were prepared (Evans et al., 1982; Mendiratta et al., 1998). Albeit circumstantial, these arguments suggest that active ascorbate transport is required to maintain the high ascorbate concentrations in cells of the vascular bed. However, DHA uptake could be important when ascorbate is rapidly oxidized outside cells, such as during the respiratory burst of phagocytic cells (Nualart et al., 2003; Washko \& Levine, 1992).

Both of the SVCT-type ascorbate transporters have been deleted in mice by targeted gene disruption. Knockout of the SVCT1 resulted in a normal appearing and fertile phenotype, but caused 2-7-fold increases in renal loss of ascorbate and 50\% decreases in plasma ascorbate (Corpe et al., 2008). This result clearly documents an important role for this transporter in ascorbate retention by the kidney. Knockout of the SVCT2 resulted in phenotypically normal and fertile heterozygotes with 40-50\% decreases in the ascorbate content of muscle and blood, despite the fact that these mice can still make ascorbate (Sotiriou et al., 2002). Although there was no fetal wastage, homozygotes died at birth with cerebral hemorrhage and failure of the lungs to expand (Sotiriou et al., 2002). Ascorbate was very low in brain, muscle, and liver (Sotiriou et al., 2002), indicating that SVCT2 is the only functional transporter in these tissues. These knockout models highlight the importance of the SVCT-type transporters to the maintenance of intracellular ascorbate concentrations in the low millimolar range.

\subsection{Ascorbate recycling in vascular cells}

Ascorbate is readily recycled from both of its oxidized forms inside cells (Fig. 2). AFR that is generated by donation of a single electron to a radical species is reduced back to ascorbate by NADH-dependent reductases present in microsomal membranes (Lumper et al., 1967; Schulze et al., 1970), as well as by cytosolic thioredoxin reductase (May et al., 1998a). AFR reduction occurs with high affinity, with apparent $K_{m}$ values for the AFR of $2 \mu M$ or less. Since ascorbate is primarily a one-electron donor, these processes likely account for the bulk of ascorbate recycling in the cell. If there is AFR generated in excess of what the enzyme systems can handle, AFR dismutation both regenerates ascorbate and forms DHA (Fig. 1). The latter is reduced by redundant high capacity but low affinity systems in all mammalian cells (Fig. 2). For example, endothelial cells and macrophages possess both GSH and NADPH-dependent mechanisms for recycling ascorbate (May et al., 2001;May et al., 2003a), although GSHdependent ascorbate recycling was not observed in HL-60 leukemic cells (Guaiquil et al., 1997), or human skin keratinocytes (Savini et al., 2000). GSH and other cellular thiols can also directly reduce DHA to ascorbate (Winkler et al., 1994), although this process is not as efficient as enzyme-mediated reduction. Since no vascular cells can synthesize ascorbate directly, their intracellular ascorbate concentrations are determined by the combined actions of ascorbate transport into the cell and recycling within the cell.

\section{Ascorbate function in endothelial cells, macrophages, and VSMCs}

\subsection{Endothelial cells}

Injury to the vascular endothelium represents a critical event for initiation of atherosclerosis (Hansson, 2005; Ross, 1999), since endothelial denudation promotes VSMC activation, 
proliferation, and migration to form the neointima (Saeed et al., 2003). Moreover, reestablishing the endothelium prevents this response (Schor et al., 1983; Ulrich-Merzenich et al., 2002) and decreases neointimal mass (Bochaton-Piallat et al., 1995). Ascorbate both stimulates proliferation of endothelial cells (Saeed et al., 2003; Schor et al., 1983) and prevents their apoptosis (Recchioni et al., 2002; Rossig et al., 2001; Saeed et al., 2003). Endothelial cell proliferation is uniquely associated with the synthesis of type IV collagen (Shekhonin et al., 1987; Thiele et al., 1992). This likely relates to the fact that type IV collagen is required for both basement membrane formation (Mercier \& Ekindjian, 1990) and endothelial cell adhesion (Rixen et al., 1989), whereas collagen types I and III collagen are not (Rixen et al., 1989). Further, there is an increase in collagen types I, III, and V in atherosclerotic plaques, but no increase in type IV collagen (Shekhonin et al., 1987), suggesting that laying down of this collagen type is not a reactive fibrosis.

As noted previously, ascorbate stimulates all types of collagen synthesis by donating electrons required for hydroxylation of proline and lysine in procollagen by specific hydroxylase enzymes (Libby \& Aikawa, 2002). This allows proper folding into the triple helical collagen molecule that is then secreted to form the extracellular matrix, or to form part of the basement membrane with regard to type IV collagen. Lack of ascorbate thus prevents generation of mature type IV collagen by cultured endothelial cells (Yoshikawa et al., 2001). In guinea pigs losing weight due to scurvy, decreases type IV collagen mRNA relative to that of elastin were evident in blood vessels (Mahmoodian \& Peterkofsky, 1999). This results in friable vessels and especially capillaries that are likely to rupture, creating the petechial hemorrhages and ecchymoses seen in scurvy and in the cerebral cortex of SVCT2 knockout mice (Sotiriou et al., 2002). Whereas deposition of any type of collagen may have the beneficial role in forming a "scar" and thus stabilizing a plaque in the vascular wall, lack of type IV collagen suggests dysfunctional or absent endothelial cells due to decreased proliferation or apoptosis.

Opposing the healing process of endothelial proliferation is apoptosis, which contributes to endothelial dysfunction (Dimmeler et al., 1998; Rossig et al., 2001). Apoptosis in endothelial cells can be induced by a variety of factors, including hyperglycemia, oxidized LDL, TNF- $\alpha$, and angiotensin II (Ho et al., 2000; Recchioni et al., 2002). Ascorbate has been shown to prevent apoptosis due to inflammatory cytokines and oxidized LDL in cultured endothelial cells (Recchioni et al., 2002; Rossig et al., 2001; Saeed et al., 2003). This is also evident in vivo as decreased release of microparticles derived from endothelial cells in subjects with congestive heart failure treated with vitamin C (Rössig et al., 2001).

Ascorbate also helps to protect the vascular endothelium by enhancing nitric oxide generation by endothelial nitric oxide synthase. Nitric oxide causes smooth muscle cell relaxation, downstream vasodilatation, and inhibits the effects of pro-inflammatory cytokines and adhesion molecules important in atherosclerosis (De Caterina et al., 1995; Khan et al., 1996; Kubes et al., 1991). Endothelial nitric oxide synthase activity is inhibited by reactive oxygen species that oxidize and thus deplete tetrahydrobiopterin, an essential co-factor for the enzyme (Kawashima \& Yokoyama, 2004; Tiefenbacher, 2001). Ascorbate prevents loss of enzyme activity, at least in part, by maintaining tetrahydrobiopterin in its reduced and active form (Heller et al., 1999; Heller et al., 2001; Huang et al., 2000). In addition to its enzymatic effects, ascorbate helps to maintain high levels of endothelial derived nitric oxide by directly reducing nitrite, by releasing nitric oxide from nitrosothiols, and by scavenging superoxide (reviewed in (May, 2000)). Regarding the latter effect, reaction of superoxide with cell-derived nitric oxide generates peroxynitrite, a strong and damaging oxidant (Beckman \& Koppenol, 1996). As noted previously, relatively high ascorbate concentrations $(>100 \mu \mathrm{M})$ are required to prevent the reaction of superoxide with nitric oxide (Jackson et al., 1998). Nonetheless, since low millimolar ascorbate concentrations are likely to be present in endothelial cells, ascorbate is probably an effective intracellular scavenger of superoxide. It thus should both prevent loss 
of nitric oxide via the reaction of nitric oxide with superoxide and decrease the generation of peroxynitrite, at least within the cell.

That ascorbate is beneficial to the endothelium in vivo is also supported by clinical studies of endothelium-dependent vasodilatation in patients with endothelial dysfunction due to atherosclerosis (Gokce et al., 1999; Heitzer et al., 2001; Tousoulis et al., 2005) and related conditions, including hypertension (Duffy et al., 1999; Duffy et al., 2001; Taddei et al., 1998), smoking (Heitzer et al., 1996; Kaufmann et al., 2000; Solzbach et al., 1997), and diabetes (Tousoulis et al., 2007). Many of the studies in atherosclerosis used high doses of intravenous ascorbate to acutely demonstrate this improvement in endothelial function in humans. Nonetheless, results of a randomized, double-blind, placebo-controlled study have shown that long term oral ascorbate supplements do have persistent effects on endothelial-dependent flowmediated brachial artery dilation (Gokce et al., 1999). In this study of 30 days duration, plasma ascorbate concentrations in 46 subjects with documented coronary artery disease were doubled by the ascorbate supplements of $500 \mathrm{mg}$ daily and flow-mediated brachial artery dilation was increased by $50 \%$. This result, in light of the multiplicity of beneficial effects of ascorbate on endothelial cell proliferation, function, and viability, makes it plausible that increases in plasma and cell ascorbate might help to prevent or delay the early endothelial dysfunction associated with atherosclerosis.

\subsection{Vascular smooth muscle cells}

In response to acute arterial injury, such as from angioplasty/stenting or from chronic injury as a result of damage by oxidized LDL, cytokines and growth factors are released from damaged endothelial and macrophage foam cells (Reidy, 1994; Ross, 1999). These in turn recruit VSMCs from the media or intima that dedifferentiate and migrate to form the neointima (Björkerud \& Björkerud, 1996; Ross, 1999). This uncontrolled proliferation of VSMCs is an important factor in the pathogenesis of both atherosclerosis and restenosis following angioplasty (Desmouliere \& Gabbiani, 1992; Ross, 1999). A role for ascorbate in preventing VSMC proliferation/dedifferentiation is suggested by the results of a clinical trial of restenosis after angioplasty, in which subjects receiving oral ascorbate supplements of $500 \mathrm{mg}$ three times daily for 4 months had $25 \%$ larger luminal diameters compared to matched controls who did not receive ascorbate. Ascorbate treatment also resulted in 50\% decreases in the need for intervention compared to the control group (Tomoda et al., 1996). Similar results were observed in studies of coronary restenosis in pigs using combinations of ascorbate and $\alpha$-tocopherol (Nunes et al., 1995; Orbe et al., 2003).

Ascorbate has several functions in activated VSMCs. It is necessary for VSMC collagen synthesis, since without it (Schwartz et al., 1982), or in the presence of the non-functional ascorbate analog ethyl-3,4-dihydroxybenzoate (Sasaki et al., 1987), VSMCs form little collagen. In addition to enhancing post-translational collagen modification in VSMCs, ascorbate also increases procollagen synthesis by a pre-translational mechanism (Barone et al., 1985; Davidson et al., 1997). Although collagen synthesis is required for VSMC migration and proliferation (Ivanov et al., 1997; Rocnik et al., 1998), the overall effect of ascorbate on these processes seems to be the opposite. For example, physiologic concentrations of ascorbate favor VSMC differentiation and gain of smooth muscle markers (Ivanov et al., 1997; Siow et al., 1998; Ulrich-Merzenich et al., 2002). Ascorbate also prevents VSMC dedifferentiation in the first place (Arakawa et al., 2000; Arakawa et al., 2003).

The disparate effects of ascorbate on VSMC collagen synthesis and differentiation have yet to be reconciled, but there is evidence that ascorbate protects VSMCs from apoptosis/necrosis due to injury by oxidized LDL. Oxidized, but not native, LDL and its reactive lipid hydroperoxides increased VSMC proliferation (Ulrich-Merzenich et al., 2002; Watanabe et al., 2001), an effect that was again paradoxically associated with increased collagen synthesis 
(Jimi et al., 1995). On the other hand, physiologic concentrations of ascorbate blocked both of these effects of oxidized LDL (Jimi et al., 1995).

\subsection{Macrophages}

Macrophages have a dual role in atherosclerosis, especially in its early stages (Hasty et al., 1999). They take up modified LDL to become the foam cells such that their numbers are significantly increased in early fatty streak lesions of adult humans, despite lack of endothelial denudation (Babaev et al., 1993). Macrophages also mediate the inflammatory response that accompanies atherosclerosis (Kanters et al., 2004). Despite the importance of macrophages in the atherosclerotic process, there is controversy regarding effects of ascorbate on macrophage function. Circumstantial evidence suggests that ascorbate is important. For example, the ascorbate content of macrophages is estimated to be several-fold higher than that of neutrophils and 40-60 times that of plasma (Oberritter et al., 1986). Further, phagocytosis of zymosan by macrophages decreased endogenous intracellular ascorbate concentrations, leading to the hypothesis that ascorbate is protective to the cells (Oberritter et al., 1986). In recent studies of thioglycollate-elicited mouse peritoneal macrophages (May et al., 2005b), ascorbate loading to intracellular concentrations of 3-10 mM prevented oxidant stress induced by latex beads. This was evident as prevention of bead-induced increases in oxidation of intracellular dihydrofluorescein and of endogenous $\alpha$-tocopherol.

In addition to decreasing oxidant stress, ascorbate has also been shown to stimulate several functions of mouse peritoneal macrophages, including adherence, chemotaxis, phagocytosis, and superoxide production (Del Rio et al., 1998). In other studies, ascorbate inhibited macrophage function by decreasing uptake and degradation of oxidized human LDL (Jialal et al., 1990; Kang et al., 2002; Retsky et al., 1993). It should be noted that the latter response has not been uniformly observed (Ashidate et al., 2003; Asmis et al., 1995), and may depend on in vitro conditions (Stait \& Leake, 1996; Stait \& Leake, 1994). Ascorbate has also been shown to enhance nitric oxide generation in macrophages by increasing the inducible isoform of nitric oxide synthase (Mizutani et al., 1998).

In contrast to endothelial cells, where there is substantial support for a beneficial effect of ascorbate in early atherosclerosis, the results in VSMCs and macrophages are more conflicting. Clearly, more research in better defined cellular models of the disease is needed with regard to these two cell types.

\section{Role of ascorbate in preventing and stabilizing atherosclerotic plaques in vivo}

Key to understanding the role of ascorbate in early atherosclerosis is the observation by Maeda et al. (Nakata \& Maeda, 2002) that ascorbate is required for synthesis of the collagenous framework of atherosclerotic plaques in apolipoprotein $\mathrm{E}$ (ApoE) knockout mice. These authors crossed mice unable to synthesize ascorbate due to targeted deletion of the gene for gulonolactone oxidase $\left(\right.$ Gulo $\left.^{(--)}\right)$with ApoE-deficient mice $\left(A p o E^{(-/)}\right)$. The mice were fed a diet either marginal in ascorbate, or a diet high in ascorbate for 4 to 9 months. It was confirmed that plasma and liver ascorbate concentrations were decreased by $70 \%$ or more in the animals on a diet marginal in ascorbate, although the animals did not have overt scurvy. After sacrifice, the expected atherosclerotic plaques were present in the aortic sinus regions of all animals, since all were $A p o E^{(-/)}$. There was no effect of either ascorbate diet on plaque size or lipid content. Although this finding does not support a role for ascorbate deficiency in early atherosclerosis, it is possible that additional factors, such as decreased vitamin E, are needed to uncover a defect or demonstrate a benefit in lesion size. 
The main finding in the study by Maeda and co-workers (Nakata \& Maeda, 2002) was that plaque collagen content was decreased $30-40 \%$ in the animals on the marginal ascorbate diet. Decreased collagen content translates to less stable atherosclerotic plaques, capable of rupture with associated thrombosis and infarction (Libby \& Aikawa, 2002). Increased collagen content and strength of the atherosclerotic plaque may also be part of the benefit afforded by lipid lowering (Aikawa et al., 1998) and statin (Fukumoto et al., 2001) therapies.

Maeda and co-workers had shown earlier that $\mathrm{Gulo}^{(-/-)}$mice on a similar diet marginal in ascorbate developed aortic lesions characterized by focal endothelial cell loss, disruption of the elastic laminae, and smooth muscle cell proliferation (Maeda et al., 2000). These two studies confirmed and extended the earlier work of Willis, in which guinea pigs developed frank atherosclerosis when made mildly scorbutic by dietary restriction of ascorbate (Willis, 1953; Willis, 1957). A role for ascorbate in plaque formation is also highlighted by the finding that the ascorbate content in plaque is several-fold that of normal artery (Suarna et al., 1995). Whereas this could indicate that additional ascorbate is not needed, it also may show how important ascorbate is to plaque remodeling and formation of a strong fibrous cap on the lesion.

\section{Conclusions}

Atherosclerosis is a disease of initial inflammation and subsequent oxidative damage. Since vitamin $\mathrm{C}$ has the potential to counteract both of these processes, it represents a practical solution for the early prevention of the disease. While a role for ascorbate in preventing human atherosclerosis still remains to be defined, mounting evidence supports a role for the vitamin in preventing endothelial dysfunction, plaque stabilization, and macrophage-dependent oxidative modification of LDL. The crux of the controversy surrounding ascorbate and atherosclerosis was perhaps best defined in another context by Dr. Albert Szent-Györgyi. Szent-Györgyi received the 1937 Nobel Prize in Physiology or Medicine, in part for his discovery that hexuronic acid, which he had isolated from adrenal gland, was indeed vitamin C. Dr. Szent-Györgyi stated in a foreword to a book authored by Irwin Stone entitled "The Healing Factor. Vitamin C Against Disease” (Stone, 1972):

“...All the same, I always had the feeling that not enough use was made of it [vitamin C] for supporting human health. The reasons are rather complex. The medical profession itself took a very narrow and very wrong view. Lack of ascorbic acid caused scurvy, so if there was no scurvy there was no lack of ascorbic acid. Nothing could be clearer than this. The only trouble was that scurvy is not a first symptom of a lack but a final collapse, a pre-mortal syndrome and there is a very wide gap between scurvy and full health."

\section{Acknowledgments}

This work was supported by NIH grant DK 50435.

\section{Abbreviations}

AFR, ascorbate free radical; ApoE, apolipoprotein E; DHA, dehydroascorbate; LDL, low density lipoprotein; SVCT, sodium-dependent vitamin C transporter; VSMCs, vascular smooth muscle cells..

\section{References}

MRC/BHF Heart Protection Study of antioxidant vitamin supplementation in 20,536 high-risk individuals: a randomised placebo-controlled trial. Lancet 2002;360:23-33. [PubMed: 12114037] 
Heart Disease and Stroke Statistics-2005 Update. American Heart Association; Dallas: 2005. Rep. No. 10

Aikawa M, Rabkin E, Okada Y, Voglic SJ, Clinton SK, Brinckerhoff CE, et al. Lipid lowering by diet reduces matrix metalloproteinase activity and increases collagen content of rabbit atheroma: a potential mechanism of lesion stabilization. Circulation 1998;97:2433-2444. [PubMed: 9641696]

Allard WJ, Lienhard GE. Monoclonal Antibodies to the Glucose Transporter from Human Erythrocytes. Identification of the Transporter as a $\mathrm{Mr}=55,000$ Protein. Journal of Biological Chemistry 1985;260:8668-8675. [PubMed: 2410404]

Arakawa E, Hasegawa K, Irie J, Ide S, Ushiki J, Yamaguchi K, et al. L-ascorbic acid stimulates expression of smooth muscle-specific markers in smooth muscle cells both in vitro and in vivo. Journal of Cardiovascular Pharmacology 2003;42:745-751. [PubMed: 14639096]

Arakawa E, Hasegawa K, Yanai N, Obinata M, Matsuda Y. A mouse bone marrow stromal cell line, TBR-B, shows inducible expression of smooth muscle-specific genes. FEBS Letters 2000;481:193196. [PubMed: 10996322]

Arrigoni O, De Tullio MC. Ascorbic acid: much more than just an antioxidant. Biochimica et Biophysica Acta: General Subjects 2002;1569:1-9.

Ashidate K, Kawamura M, Tohda H, Miyazaki S, Hayashi H, Teramoto T, et al. Ascorbic acid augments cytotoxicity induced by oxidized low-density lipoprotein. J.Atheroscler.Thromb 2003;10:7-12. [PubMed: 12621158]

Asmis R, Llorente VC, Gey KF. Prevention of cholesteryl ester accumulation in P388D1 macrophagelike cells by increased cellular vitamin $\mathrm{E}$ depends on species of extracellular cholesterol. Conventional heterologous non-human cell cultures are poor models of human atherosclerotic foam cell formation. European Journal of Biochemistry 1995;233:171-178. [PubMed: 7588742]

Babaev VR, Bobryshev YV, Sukhova GK, Kasantseva IA. Monocyte/macrophage accumulation and smooth muscle cell phenotypes in early atherosclerotic lesions of human aorta. Atherosclerosis 1993;100:237-248. [PubMed: 8357356]

Barone LM, Faris B, Chipman SD, Toselli P, Oakes BW, Franzblau C. Alteration of the extracellular matrix of smooth muscle cells by ascorbate treatment. Biochimica et Biophysica Acta 1985;840:245254. [PubMed: 2859894]

Beckman JS, Koppenol WH. Nitric oxide, superoxide, and peroxynitrite: The good, the bad, and the ugly. American Journal of Physiology: Cell Physiology 1996;271:C1424-C1437.

Bergsten P, Amitai G, Kehrl J, Dhariwal KR, Klein HG, Levine M. Millimolar concentrations of ascorbic acid in purified human mononuclear leukocytes. Depletion and reaccumulation. Journal of Biological Chemistry 1990;265:2584-2587. [PubMed: 2303417]

Berliner JA, Heinecke JW. The role of oxidized lipoproteins in atherogenesis. Free Radical Biology and Medicine 1996;20:707-727. [PubMed: 8721615]

Best KA, Holmes ME, Samson SE, Mwanjewe J, Wilson JX, Dixon SJ, et al. Ascorbate uptake in pig coronary artery endothelial cells. Mol.Cell Biochem 2005;271:43-49. [PubMed: 15881654]

Bielski BH, Richter HW, Chan PC. Some properties of the ascorbate free radical. Annals of the New York Academy of Sciences 1975;258:231-237. [PubMed: 942]

Björkerud B, Björkerud S. Contrary effects of lightly and strongly oxidized LDL with potent promotion of growth versus apoptosis on arterial smooth muscle cells, macrophages, and fibroblasts. Arteriosclerosis, Thrombosis, and Vascular Biology 1996;16:416-424.

Blumberg JB, Frei B. Why clinical trials of vitamin E and cardiovascular diseases may be fatally flawed. Commentary on "The relationship between dose of vitamin E and suppression of oxidative stress in humans”. Free Radical Biology and Medicine 2007;43:1374-1376. [PubMed: 17936183]

Bochaton-Piallat ML, Gabbiani F, Redard M, Desmouliere A, Gabbiani G. Apoptosis participates in cellularity regulation during rat aortic intimal thickening. Am.J Pathol 1995;146:1059-1064. [PubMed: 7747800]

Bode AM, Cunningham L, Rose RC. Spontaneous decay of oxidized ascorbic acid (dehydro-L-ascorbic acid) evaluated by high-pressure liquid chromatography. Clinical Chemistry 1990;36:1807-1809. [PubMed: 2208658]

Bruick RK, McKnight SL. A conserved family of prolyl-4-hydroxylases that modify HIF. Science 2001;294:1337-1340. [PubMed: 11598268] 
Bruno RS, Leonard SW, Atkinson J, Montine TJ, Ramakrishnan R, Bray TM, et al. Faster plasma vitamin E disappearance in smokers is normalized by vitamin $C$ supplementation. Free Radical Biology and Medicine 2006;40:689-697. [PubMed: 16458200]

Bruno RS, Ramakrishnan R, Montine TJ, Bray TM, Traber MG. $\alpha$-Tocopherol disappearance is faster in cigarette smokers and is inversely related to their ascorbic acid status. American Journal of Clinical Nutrition 2005;81:95-103. [PubMed: 15640466]

Buettner GR. The pecking order of free radicals and antioxidants: lipid peroxidation, alpha-tocopherol, and ascorbate. Archives of Biochemistry and Biophysics 1993;300:535-543. [PubMed: 8434935]

Buettner GR, Jurkiewicz BA. Catalytic metals, ascorbate and free radicals: Combinations to avoid. Radiation Research 1996;145:532-541. [PubMed: 8619018]

Buettner GR, Jurkiewicz BA. Ascorbate free radical as a marker of oxidative stress: an EPR study. Free Radical Biology and Medicine 1993;14:49-55. [PubMed: 8384150]

Carr A, Frei B. Does vitamin C act as a pro-oxidant under physiological conditions? FASEB Journal 1999;13:1007-1024. [PubMed: 10336883]

Chatterjee IB. Biosynthesis of L-ascorbate in animals. Methods in Enzymology 1970;18:28-34.

Chatterjee IB, Majumder AK, Nandi BK, Subramanian N. Synthesis and some major functions of vitamin C in animals. Ann.N.Y.Acad.Sci 1975;258:24-47. [PubMed: 1106297]

Chen X, Touyz RM, Park JB, Schiffrin EL. Antioxidant effects of vitamins C and E are associated with altered activation of vascular NADPH oxidase and superoxide dismutase in stroke-prone SHR. Hypertension 2001;38:606-611. [PubMed: 11566940]

Coassin M, Tomasi A, Vannini V, Ursini F. Enzymatic recycling of oxidized ascorbate in pig heart: oneelectron vs two-electron pathway. Archives of Biochemistry and Biophysics 1991;290:458-462. [PubMed: 1929413]

Corpe C, Tu H, Wang J, Eck P, Wang Y, Schnermann J, et al. SVCT1 (Slc23a1) knockout mice: Slc23a1 as the vitamin C kidney reabsorptive transporter. The FASEB Journal 2008;21:LB111.Meeting abstract

Davidson JM, LuValle PA, Zoia O, Quaglino D Jr. Giro M. Ascorbate differentially regulates elastin and collagen biosynthesis in vascular smooth muscle cells and skin fibroblasts by pretranslational mechanisms. J Biol Chem 1997;272:345-352. [PubMed: 8995268]

De Caterina R, Libby P, Peng HB, Thannickal VJ, Rajavashisth TB, Gimbrone MA Jr. et al. Nitric oxide decreases cytokine-induced endothelial activation. Nitric oxide selectively reduces endothelial expression of adhesion molecules and proinflammatory cytokines. J.Clin.Invest 1995;96:60-68. [PubMed: 7542286]

Del Rio M, Ruedas G, Medina S, Victor VM, De la FM. Improvement by several antioxidants of macrophage function in vitro. Life Sciences 1998;63:871-881. [PubMed: 9734707]

Desmouliere A, Gabbiani G. The cytoskeleton of arterial smooth muscle cells during human and experimental atheromatosis. Kidney Int.Suppl 1992;37:S87-S89. [PubMed: 1630078]

Dhariwal KR, Hartzell WO, Levine M. Ascorbic acid and dehydroascorbic acid measurements in human plasma and serum. American Journal of Clinical Nutrition 1991;54:712-716. [PubMed: 1897478]

Dimmeler S, Hermann C, Zeiher AM. Apoptosis of endothelial cells. Contribution to the pathophysiology of atherosclerosis? Eur.Cytokine Netw 1998;9:697-698. [PubMed: 9889419]

Drake BB, Smythe CV, King CG. Complexes of dehydroascorbic acid with three sulfhydryl compounds. Journal of Biological Chemistry 1942;143:89-98.

Duffy SJ, Gokce N, Holbrook M, Huang A, Frei B, Keaney JF Jr. et al. Treatment of hypertension with ascorbic acid. Lancet 1999;354:2048-2049. [PubMed: 10636373]

Duffy SJ, Gokce N, Holbrook M, Hunter LM, Biegelsen ES, Huang AO, et al. Effect of ascorbic acid treatment on conduit vessel endothelial dysfunction in patients with hypertension. American Journal of Physiology: Heart and Circulatory Physiology 2001;280:H528-H534. [PubMed: 11158948]

Ek A, Ström K, Cotgreave IA. The uptake of ascorbic acid into human umbilical vein endothelial cells and its effect on oxidant insult. Biochemical Pharmacology 1995;50:1339-1346. [PubMed: 7503781]

Esterbauer H, Dieber-Rotheneder M, Waeg G, Striegl G, Jürgens G. Biochemical, structural, and functional properties of oxidized low-density lipoprotein. Chem.Res.Toxicol 1990;3:77-92. [PubMed: 2130945] 
Evans RM, Currie L, Campbell A. The distribution of ascorbic acid between various cellular components of blood, in normal individuals, and its relation to the plasma concentration. British Journal of Nutrition 1982;47:473-482. [PubMed: 7082619]

Frei B. Ascorbic acid protects lipids in human plasma and low-density lipoprotein against oxidative damage. American Journal of Clinical Nutrition 1991;54:1113S-1118S. [PubMed: 1962556]

Frei B, England L, Ames BN. Ascorbate is an outstanding antioxidant in human blood plasma. Proceedings of the National Academy of Sciences of the United States of America 1989;86:63776381. [PubMed: 2762330]

Fukumoto Y, Libby P, Rabkin E, Hill CC, Enomoto M, Hirouchi Y, et al. Statins alter smooth muscle cell accumulation and collagen content in established atheroma of Watanabe heritable hyperlipidemic rabbits. Circulation 2001;103:993-999. [PubMed: 11181475]

Glascott PA Jr. Gilfor E, Serroni A, Farber JL. Independent antioxidant action of vitamins E and C in cultured rat hepatocytes intoxicated with allyl alcohol. Biochemical Pharmacology 1996;52:12451252. [PubMed: 8937432]

Gokce N, Keaney JF Jr. Frei B, Holbrook M, Olesiak M, Zachariah BJ, et al. Long-term ascorbic acid administration reverses endothelial vasomotor dysfunction in patients with coronary artery disease. Circulation 1999;99:3234-3240. [PubMed: 10385496]

Guaiquil VH, Farber CM, Golde DW, Vera JC. Efficient transport and accumulation of vitamin C in HL-60 cells depleted of glutathione. Journal of Biological Chemistry 1997;272:9915-9921. [PubMed: 9092530]

Halliwell B. Vitamin C: poison, prophylactic or panacea? Trends in Biochemical Sciences 1999;24:255259. [PubMed: 10390611]

Hansson GK. Inflammation, atherosclerosis, and coronary artery disease. New England Journal of Medicine 2005;352:1685-1695. [PubMed: 15843671]

Hasty AH, Linton MF, Brandt SJ, Babaev VR, Gleaves LA, Fazio S. Retroviral gene therapy in ApoEdeficient mice: ApoE expression in the artery wall reduces early foam cell lesion formation. Circulation 1999;99:2571-2576. [PubMed: 10330390]

Heitzer T, Just H, Münzel T. Antioxidant vitamin C improves endothelial dysfunction in chronic smokers. Circulation 1996;94:6-9. [PubMed: 8964118]

Heitzer T, Schlinzig T, Krohn K, Meinertz T, Münzel T. Endothelial dysfunction, oxidative stress, and risk of cardiovascular events in patients with coronary artery disease. Circulation 2001;104:26732678. [PubMed: 11723017]

Heller R, Münscher-Paulig F, Gräbner R, Till U. L-ascorbic acid potentiates nitric oxide synthesis in endothelial cells. Journal of Biological Chemistry 1999;274:8254-8260. [PubMed: 10075731]

Heller R, Unbehaun A, Schellenberg B, Mayer B, Werner-Felmayer G, Werner ER. L-ascorbic acid potentiates endothelial nitric oxide synthesis via a chemical stabilization of tetrahydrobiopterin. Journal of Biological Chemistry 2001;276:40-47. [PubMed: 11022034]

Ho FM, Liu SH, Liau CS, Huang PJ, Lin-Shiau SY. High glucose-induced apoptosis in human endothelial cells is mediated by sequential activations of c-Jun $\mathrm{NH}_{2}$-terminal kinase and caspase-3. Circulation 2000;101:2618-2624. [PubMed: 10840014]

Holmes ME, Samson SE, Wilson JX, Dixon SJ, Grover AK. Ascorbate transport in pig coronary artery smooth muscle: $\mathrm{Na}^{+}$removal and oxidative stress increase loss of accumulated cellular ascorbate. Journal of Vascular Research 2000;37:390-398. [PubMed: 11025402]

Huang A, Vita JA, Venema RC, Keaney JF Jr. Ascorbic acid enhances endothelial nitric-oxide synthase activity by increasing intracellular tetrahydrobiopterin. Journal of Biological Chemistry 2000;275:17399-17406. [PubMed: 10749876]

Huang J, May JM. Ascorbic acid spares $\alpha$-tocopherol and prevents lipid peroxidation in cultured H4IIE liver cells. Molecular and Cellular Biochemistry 2003;247:171-176. [PubMed: 12841645]

Ivanov VO, Ivanova SV, Niedzwiecki A. Ascorbate affects proliferation of guinea-pig vascular smooth muscle cells by direct and extracellular matrix-mediated effects. Journal of Molecular and Cellular Cardiology 1997;29:3293-3303. [PubMed: 9441835]

Jackson TS, Xu AM, Vita JA, Keaney JF Jr. Ascorbate prevents the interaction of superoxide and nitric oxide only at very high physiological concentrations. Circulation Research 1998;83:916-922. [PubMed: 9797340] 
Jialal I, Vega GL, Grundy SM. Physiologic levels of ascorbate inhibit the oxidative modification of low density lipoprotein. Atherosclerosis 1990;82:185-191. [PubMed: 2375783]

Jimi S, Saku K, Uesugi N, Sakata N, Takebayashi S. Oxidized low density lipoprotein stimulates collagen production in cultured arterial smooth muscle cells. Atherosclerosis 1995;116:15-26. [PubMed: 7488330]

Kang YH, Park SH, Lee YJ, Kang JS, Kang IJ, Shin HK, et al. Antioxidant alpha-keto-carboxylate pyruvate protects low-density lipoprotein and atherogenic macrophages. Free Radic.Res 2002;36:905-914. [PubMed: 12420749]

Kanters E, Gijbels MJ, van d. M. Vergouwe MN, Heeringa P, Kraal G, et al. Hematopoietic NF-kB1 deficiency results in small atherosclerotic lesions with an inflammatory phenotype. Blood 2004;103:934-940. [PubMed: 14512319]I

Kaufmann PA, Gnecchi-Ruscone T, Di Terlizzi M, Schäfers KP, Lüscher TF, Camici PG. Coronary heart disease in smokers - Vitamin $\mathrm{C}$ restores coronary microcirculatory function. Circulation 2000;102:1233-1238. [PubMed: 10982536]

Kawashima S, Yokoyama M. Dysfunction of endothelial nitric oxide synthase and atherosclerosis. Arteriosclerosis, Thrombosis, and Vascular Biology 2004;24:998-1005.

Khan BV, Harrison DG, Olbrych MT, Alexander RW, Medford RM. Nitric oxide regulates vascular cell adhesion molecule 1 gene expression and redox-sensitive transcriptional events in human vascular endothelial cells. Proc.Natl.Acad.Sci.U.S.A 1996;93:9114-9119. [PubMed: 8799163]

Kris-Etherton PM, Lichtenstein AH, Howard BV, Steinberg D, Witztum JL. Antioxidant vitamin supplements and cardiovascular disease. Circulation 2004;110:637-641. [PubMed: 15289389]

Kubes P, Suzuki M, Granger DN. Nitric oxide: an endogenous modulator of leukocyte adhesion. Proc.Natl.Acad.Sci.U.S.A 1991;88:4651-4655. [PubMed: 1675786]

LaRosa JC, He J, Vupputuri S. Effect of statins on risk of coronary disease: a meta-analysis of randomized controlled trials. Journal of the American Medical Association 1999;282:2340-2346. [PubMed: 10612322]

Levine M, Wang YH, Padayatty SJ, Morrow J. A new recommended dietary allowance of vitamin C for healthy young women. Proceedings of the National Academy of Sciences of the United States of America 2001;98:9842-9846. [PubMed: 11504949]

Li X, Huang J, May JM. Ascorbic acid spares alpha-tocopherol and decreases lipid peroxidation in neuronal cells. Biochemical and Biophysical Research Communications 2003;305:656-661. [PubMed: 12763044]

Libby P, Aikawa M. Vitamin C, collagen, and cracks in the plaque. Circulation 2002;105:1396-1398. [PubMed: 11914242]

Lumper L, Schneider W, Staudinger H. Untersuchungen zur Kinetik der mikrosomalen NADH:Semidehydroascorbat-Oxydoreduktase. Hoppe Seylers.Z.Physiol.Chem 1967;348:323-328. [PubMed: 4385354]

Lykkesfeldt J, Christen S, Wallock LM, Chang HH, Jacob RA, Ames BN. Ascorbate is depleted by smoking and repleted by moderate supplementation: a study in male smokers and nonsmokers with matched dietary antioxidant intakes. American Journal of Clinical Nutrition 2000;71:530-536. [PubMed: 10648268]

Maeda N, Hagihara H, Nakata Y, Hiller S, Wilder J, Reddick R. Aortic wall damage in mice unable to synthesize ascorbic acid. Proceedings of the National Academy of Sciences of the United States of America 2000;97:841-846. [PubMed: 10639167]

Mahmoodian F, Peterkofsky B. Vitamin C deficiency in guinea pigs differentially affects the expression of type IV collagen, laminin, and elastin in blood vessels. J Nutr 1999;129:83-91. [PubMed: 9915880]

Martin A, Frei B. Both intracellular and extracellular vitamin C inhibit atherogenic modification of LDL by human vascular endothelial cells. Arteriosclerosis, Thrombosis, and Vascular Biology 1997; 17:1583-1590.

May JM. How does ascorbic acid prevent endothelial dysfunction? Free Radical Biology and Medicine 2000;28:1421-1429. [PubMed: 10924860] 
May JM, Cobb CE, Mendiratta S, Hill KE, Burk RF. Reduction of the ascorbyl free radical to ascorbate by thioredoxin reductase. Journal of Biological Chemistry 1998a;273:23039-23045. [PubMed: 9722529]

May JM, Huang J, Qu ZC. Macrophage uptake and recycling of ascorbic acid: Response to activation by lipopolysaccharide. Free Radical Biology and Medicine 2005a;39:1449-1459. [PubMed: 16274880]

May JM, Li L, Qu ZC, Huang J. Ascorbate uptake and antioxidant function in peritoneal macrophages. Archives of Biochemistry and Biophysics 2005b;440:165-172. [PubMed: 16054587]

May JM, Qu ZC. Transport and intracellular accumulation of vitamin C in endothelial cells: relevance to collagen synthesis. Archives of Biochemistry and Biophysics 2005;434:178-186. [PubMed: 15629121]

May JM, Qu ZC, Li X. Requirement for GSH in recycling of ascorbic acid in endothelial cells. Biochemical Pharmacology 2001;62:873-881. [PubMed: 11543722]

May JM, Qu ZC, Neel DR, Li X. Recycling of vitamin C from its oxidized forms by human endothelial cells. Biochimica et Biophysica Acta: Molecular Cell Research 2003a;1640:153-161.

May JM, Qu ZC, Qiao H, Koury MJ. Maturational loss of the vitamin C transporter in erythrocytes. Biochemical and Biophysical Research Communications 2007;360:295-298. [PubMed: 17586466]

May JM, Qu Z-C, Li X. Ascorbic acid blunts oxidant stress due to menadione in endothelial cells. Archives of Biochemistry and Biophysics 2003b;411:136-144. [PubMed: 12590932]

May JM, Qu Z-C, Mendiratta S. Protection and recycling of $\alpha$-tocopherol in human erythrocytes by intracellular ascorbic acid. Archives of Biochemistry and Biophysics 1998b;349:281-289. [PubMed: 9448716]

Mehlhorn RJ. Ascorbate- and dehydroascorbic acid-mediated reduction of free radicals in the human erythrocyte. Journal of Biological Chemistry 1991;266:2724-2731. [PubMed: 1993652]

Mendiratta S, Qu Z-C, May JM. Erythrocyte ascorbate recycling: Antioxidant effects in blood. Free Radical Biology and Medicine 1998;24:789-797. [PubMed: 9586809]

Mercier P, Ekindjian OG. Collagen type IV: major component of basement membranes. Current knowledge. Ann.Biol Clin.(Paris) 1990;48:695-711. [PubMed: 2082758]

Mizutani A, Maki H, Torii Y, Hitomi K, Tsukagoshi N. Ascorbate-dependent enhancement of nitric oxide formation in activated macrophages. Nitric.Oxide 1998;2:235-241. [PubMed: 9851364]

Myllylä R, Majamaa K, Gunzler V, Hanauske-Abel HM, Kivirikko KI. Ascorbate is consumed stoichiometrically in the uncoupled reactions catalyzed by prolyl 4-hydroxylase and lysyl hydroxylase. Journal of Biological Chemistry 1984;259:5403-5405. [PubMed: 6325436]

Nakata Y, Maeda N. Vulnerable atherosclerotic plaque morphology in apolipoprotein E-deficient mice unable to make ascorbic acid. Circulation 2002;105:1485-1490. [PubMed: 11914259]

Nespereira B, Perez-Ilzarbe M, Fernandez P, Fuentes AM, Paramo JA, Rodriguez JA. Vitamins C and E downregulate vascular VEGF and VEGFR-2 expression in apolipoprotein-E-deficient mice. Atherosclerosis 2003;171:67-73. [PubMed: 14642407]

Niki E, Noguchi N, Tsuchihashi H, Gotoh N. Interaction among vitamin C, vitamin E, and $\beta$-carotene. American Journal of Clinical Nutrition 1995;62(Suppl):1322S-1326S. [PubMed: 7495227]

Nishikimi M, Fukuyama R, Minoshima S, Shimizu N, Yagi K. Cloning and chromosomal mapping of the human nonfunctional gene for L-gulono-gamma-lactone oxidase, the enzyme for L-ascorbic acid biosynthesis missing in man. Journal of Biological Chemistry 1994;269:13685-13688. [PubMed: 8175804]

Nualart FJ, Rivas CI, Montecinos VP, Godoy AS, Guaiquil VH, Golde DW, et al. Recycling of vitamin C by a bystander effect. Journal of Biological Chemistry 2003;278:10128-10133. [PubMed: 12435736]

Nunes GL, Sgoutas DS, Redden RA, Sigman SR, Gravanis MB, King SB III, et al. Combination of vitamins $\mathrm{C}$ and $\mathrm{E}$ alters the response to coronary balloon injury in the pig. Arterioscler.Thromb 1995;15:156-165.

Oberritter H, Glatthaar B, Moser U, Schmidt KH. Effect of functional stimulation on ascorbate content in phagocytes under physiological and pathological conditions. Int.Arch.Allergy Appl.Immunol 1986;81:46-50. [PubMed: 3744577] 
Orbe J, Rodriguez JA, Arias R, Belzunce M, Nespereira B, Perez-Ilzarbe M, et al. Antioxidant vitamins increase the collagen content and reduce MMP-1 in a porcine model of atherosclerosis: implications for plaque stabilization. Atherosclerosis 2003;167:45-53. [PubMed: 12618267]

Price KD, Price CS, Reynolds RD. Hyperglycemia-induced latent scurvy and atherosclerosis: the scorbutic-metaplasia hypothesis. Medical Hypotheses 1996;46:119-129. [PubMed: 8692035]

Qiao H, May JM. Development of ascorbate transport in brain capillary endothelial cells in culture. Brain Research 2008;1208:79-86. [PubMed: 18394593]

Recchioni R, Marcheselli F, Moroni F, Pieri C. Apoptosis in human aortic endothelial cells induced by hyperglycemic condition involves mitochondrial depolarization and is prevented by $N$-acetyl-Lcysteine. Metabolism: Clinical and Experimental 2002;51:1384-1388. [PubMed: 12404184]

Reidy MA. Growth factors and arterial smooth muscle cell proliferation. Ann.N.Y.Acad.Sci 1994;714:225-230. [PubMed: 8017771]

Retsky KL, Freeman MW, Frei B. Ascorbic acid oxidation product(s) protect human low density lipoprotein against atherogenic modification. Anti- rather than prooxidant activity of vitamin $\mathrm{C}$ in the presence of transition metal ions. Journal of Biological Chemistry 1993;268:1304-1309. [PubMed: 8419332]

Rixen H, Kirkpatrick CJ, Schmitz U, Ruchatz D, Mittermayer C. Interaction between endothelial cells and basement membrane components. In vitro studies on endothelial cell adhesion to collagen types I, III, IV and high molecular weight fragments of IV. Exp.Cell Biol 1989;57:315-323. [PubMed: 2535276]

Roberts LJ, Oates JA, Linton MF, Fazio S, Meador BP, Gross MD, et al. The relationship between dose of vitamin $\mathrm{E}$ and suppression of oxidative stress in humans. Free Radical Biology and Medicine 2007;43:1388-1393. [PubMed: 17936185]

Rocnik EF, Chan BM, Pickering JG. Evidence for a role of collagen synthesis in arterial smooth muscle cell migration. J Clin.Invest 1998;101:1889-1898. [PubMed: 9576753]

Rodriguez JA, Nespereira B, Perez-Ilzarbe M, Eguinoa E, Paramo JA. Vitamins C and E prevent endothelial VEGF and VEGFR-2 overexpression induced by porcine hypercholesterolemic LDL. Cardiovasc.Res 2005;65:665-673. [PubMed: 15664393]

Rose RC. Transport of ascorbic acid and other water-soluble vitamins. Biochimica et Biophysica Acta 1988;947:335-366. [PubMed: 3285893]

Ross R. Atherosclerosis--an inflammatory disease. New England Journal of Medicine 1999;340:115126. [PubMed: 9887164]

Rossig L, Dimmeler S, Zeiher AM. Apoptosis in the vascular wall and atherosclerosis. Basic Res.Cardiol 2001;96:11-22. [PubMed: 11215528]

Rössig L, Hoffmann J, Hugel B, Mallat Z, Haase A, Freyssinet JM, et al. Vitamin C inhibits endothelial cell apoptosis in congestive heart failure. Circulation 2001;104:2182-2187. [PubMed: 11684628]

Sabharwal AK, May JM. alpha-Lipoic acid and ascorbate prevent LDL oxidation and oxidant stress in endothelial cells. Mol.Cell Biochem 2008;309:125-132. [PubMed: 18026819]

Saeed RW, Peng T, Metz CN. Ascorbic acid blocks the growth inhibitory effect of tumor necrosis factoralpha on endothelial cells. Exp.Biol Med.(Maywood.) 2003;228:855-865. [PubMed: 12876306]

Sasaki T, Majamaa K, Uitto J. Reduction of collagen production in keloid fibroblast cultures by ethyl-3,4dihydroxybenzoate. Inhibition of prolyl hydroxylase activity as a mechanism of action. J Biol Chem 1987;262:9397-9403. [PubMed: 3036858]

Savini I, Duflot S, Avigliano L. Dehydroascorbic acid uptake in a human keratinocyte cell line (HaCaT) is glutathione-independent. Biochemical Journal 2000;345:665-672. [PubMed: 10642526]

Schectman G, Byrd JC, Gruchow HW. The influence of smoking on vitamin C status in adults. Am.J.Public Health 1989;79:158-162. [PubMed: 2913833]

Schor AM, Schor SL, Allen TD. Effects of culture conditions on the proliferation, morphology and migration of bovine aortic endothelial cells. J.Cell Sci 1983;62:267-285. [PubMed: 6619206]

Schulze H-U, Gallenkamp H, Staudinger H. Untersuchungen zum mikrosomalen NADH-abhängigen Elektronentransport. Hoppe Seylers.Z.Physiol.Chem 1970;351:809-817. [PubMed: 4317422]

Schwartz E, Bienkowski RS, Coltoff-Schiller B, Goldfischer S, Blumenfeld OO. Changes in the components of extracellular matrix and in growth properties of cultured aortic smooth muscle cells upon ascorbate feeding. J Cell Biol 1982;92:462-470. [PubMed: 7061590] 
Shekhonin BV, Domogatsky SP, Idelson GL, Koteliansky VE, Rukosuev VS. Relative distribution of fibronectin and type I, III, IV, V collagens in normal and atherosclerotic intima of human arteries. Atherosclerosis 1987;67:9-16. [PubMed: 3314885]

Siow RC, Sato H, Leake DS, Pearson JD, Bannai S, Mann GE. Vitamin C protects human arterial smooth muscle cells against atherogenic lipoproteins - Effects of antioxidant vitamins $\mathrm{C}$ and $\mathrm{E}$ on oxidized LDL-induced adaptive increases in cystine transport and glutathione. Arteriosclerosis, Thrombosis, and Vascular Biology 1998;18:1662-1670.

Solzbach U, Hornig B, Jeserich M, Just H. Vitamin C improves endothelial dysfunction of epicardial coronary arteries in hypertensive patients. Circulation 1997;96:1513-1519. [PubMed: 9315540]

Sotiriou S, Gispert S, Cheng J, Wang YH, Chen A, Hoogstraten-Miller S, et al. Ascorbic-acid transporter Slc23a1 is essential for vitamin $\mathrm{C}$ transport into the brain and for perinatal survival. Nature Medicine 2002;8:514-517.

Stait SE, Leake DS. The effects of ascorbate and dehydroascorbate on the oxidation of low-density lipoprotein. Biochemical Journal 1996;320:373-381. [PubMed: 8973543]

Stait SE, Leake DS. Ascorbic acid can either increase or decrease low density lipoprotein modification. FEBS Letters 1994;341:263-267. [PubMed: 8137950]

Stocker R, Keaney JF Jr. Role of oxidative modifications in atherosclerosis. Physiol Rev 2004;84:13811478. [PubMed: 15383655]

Stocker R, Keaney JF Jr. New insights on oxidative stress in the artery wall. J.Thromb.Haemost 2005;3:1825-1834. [PubMed: 16102049]

Stone, I. The Healing Factor. Vitamin C Against Disease. 1 ed.. Putnam Publishing Group; New York, New York: 1972.

Suarna C, Dean RT, May J, Stocker R. Human atherosclerotic plaque contains both oxidized lipids and relatively large amounts of alpha-tocopherol and ascorbate. Arteriosclerosis, Thrombosis, and Vascular Biology 1995;15:1616-1624.

Taddei S, Virdis A, Ghiadoni L, Magagna A, Salvetti A. Vitamin C improves endothelium-dependent vasodilation by restoring nitric oxide activity in essential hypertension. Circulation 1998;97:22222229. [PubMed: 9631871]

Thiele J, Rompcik V, Wagner S, Fischer R. Vascular architecture and collagen type IV in primary myelofibrosis and polycythaemia vera: an immunomorphometric study on trephine biopsies of the bone marrow. Br.J Haematol 1992;80:227-234. [PubMed: 1550781]

Thomas SR, Stocker R. Molecular action of vitamin E in lipoprotein oxidation: Implications for atherosclerosis. Free Radical Biology and Medicine 2000;28:1795-1805. [PubMed: 10946221]

Tiefenbacher CP. Tetrahydrobiopterin: a critical cofactor for eNOS and a strategy in the treatment of endothelial dysfunction? American Journal of Physiology: Heart and Circulatory Physiology 2001;280:H2484-H2488. [PubMed: 11356602]

Tomoda H, Yoshitake M, Morimoto K, Aoki N. Possible prevention of postangioplasty restenosis by ascorbic acid. American Journal of Cardiology 1996;78:1284-1286. [PubMed: 8960592]

Tousoulis D, Antoniades C, Vasiliadou C, Kourtellaris P, Koniari K, Marinou K, et al. Effects of atorvastatin and vitamin $\mathrm{C}$ on forearm hyperaemic blood flow, asymmentrical dimethylarginine levels and the inflammatory process in patients with type 2 diabetes mellitus. Heart 2007;93:244246. [PubMed: 16914485]

Tousoulis D, Xenakis C, Tentolouris C, Davies G, Antoniades C, Crake T, et al. Effects of vitamin C on intracoronary L-arginine dependent coronary vasodilatation in patients with stable angina. Heart 2005;91:1319-1323. [PubMed: 16162626]

Tsukaguchi H, Tokui T, Mackenzie B, Berger UV, Chen X-Z, Wang YX, et al. A family of mammalian $\mathrm{Na}^{+}$-dependent L-ascorbic acid transporters. Nature 1999;399:70-75. [PubMed: 10331392]

Ulrich-Merzenich G, Metzner C, Schiermeyer B, Vetter H. Vitamin C and vitamin E antagonistically modulate human vascular endothelial and smooth muscle cell DNA synthesis and proliferation. Eur.J Nutr 2002;41:27-34. [PubMed: 11990005]

Voskoboinik I, Soderholm K, Cotgreave IA. Ascorbate and glutathione homeostasis in vascular smooth muscle cells: cooperation with endothelial cells. Am.J Physiol 1998;275:C1031-C1039. [PubMed: 9755056] 
Washko P, Levine M. Inhibition of ascorbic acid transport in human neutrophils by glucose. Journal of Biological Chemistry 1992;267:23568-23574. [PubMed: 1429700]

Watanabe T, Pakala R, Katagiri T, Benedict CR. Lipid peroxidation product 4-hydroxy-2-nonenal acts synergistically with serotonin in inducing vascular smooth muscle cell proliferation. Atherosclerosis 2001;155:37-44. [PubMed: 11223424]

Willis GC. An experimental study of the intimal ground substance in atherosclerosis. Canadian Medical Association Journal 1953;69:17-22. [PubMed: 13059725]

Willis GC. The reversibility of atherosclerosis. Can.Med.Assoc.J 1957;77:106-108. [PubMed: 13446787]

Winkler BS. In vitro oxidation of ascorbic acid and its prevention by GSH. Biochimica et Biophysica Acta 1987;925:258-264. [PubMed: 3620500]

Winkler BS, Orselli SM, Rex TS. The redox couple between glutathione and ascorbic acid: A chemical and physiological perspective. Free Radical Biology and Medicine 1994;17:333-349. [PubMed: 8001837]

Witztum JL, Steinberg D. The oxidative modification hypothesis of atherosclerosis: does it hold for humans? Trends Cardiovasc.Med 2001;11:93-102. [PubMed: 11686009]

Yoshikawa K, Takahashi S, Imamura Y, Sado Y, Hayashi T. Secretion of non-helical collagenous polypeptides of alpha1(IV) and alpha2(IV) chains upon depletion of ascorbate by cultured human cells. Journal of Biochemistry 2001;129:929-936. [PubMed: 11388908] 


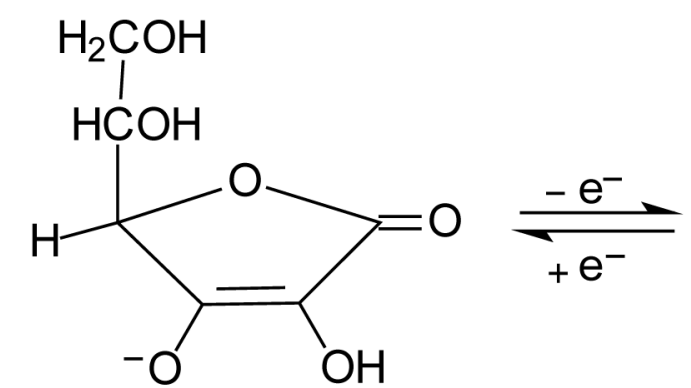

Ascorbic Acid

$$
\mathrm{H}_{2}^{\mathrm{COH}}
$$<smiles>CC1OC(=O)C(=O)C(=O)O1</smiles>

Ascorbate Free Radical (AFR)

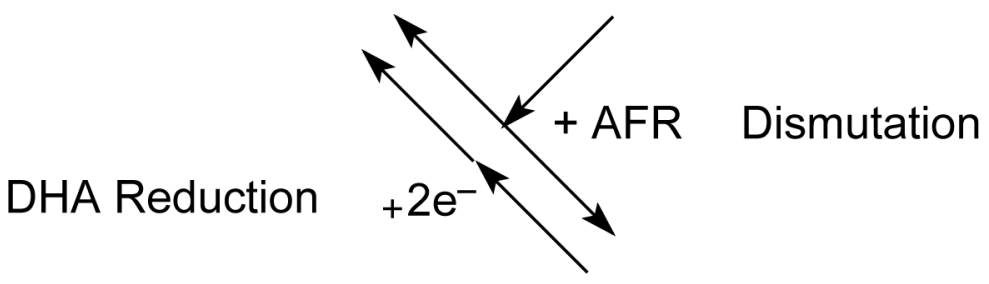

$\mathrm{H}_{2} \mathrm{COH}$<smiles>CC(O)C(O)C(=O)C(=O)C(=O)[O-]</smiles>

2,3-Diketo-1-gulonic Acid

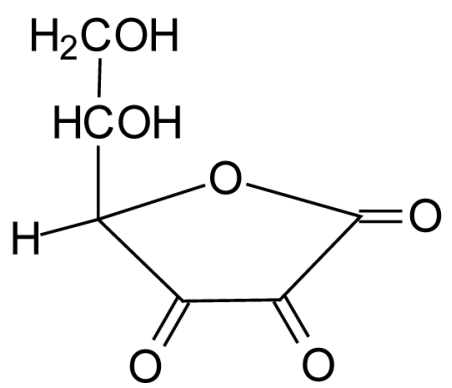

Dehydroascorbate

Figure 1.

Ascorbate oxidation and recycling. 


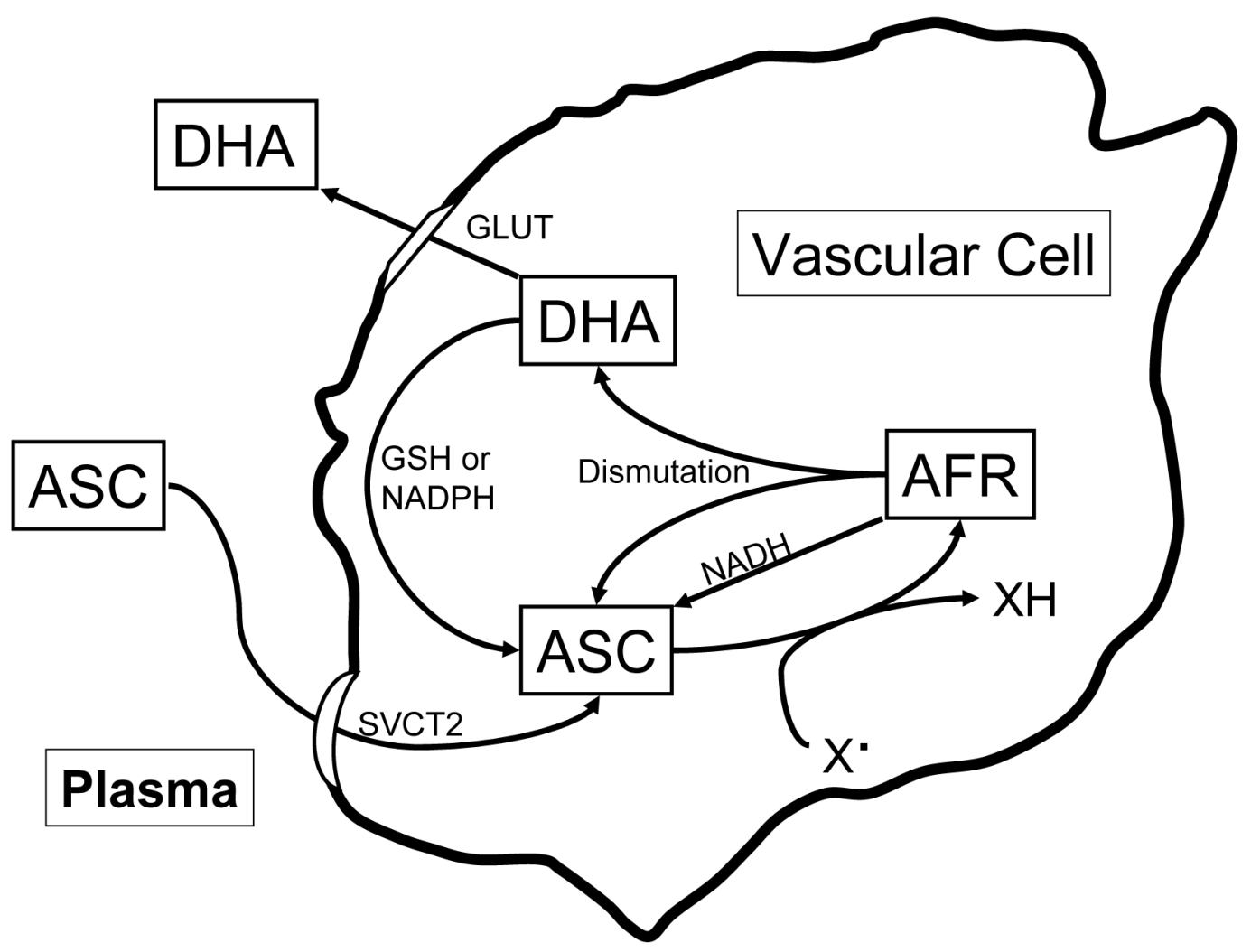

Figure 2.

Ascorbate uptake metabolism in vascular cells. Ascorbate is taken up from plasma or the interstitium on the ascorbate transporter (SVCT2). Once in the cell it can undergo one-electron oxidation by radical oxygen- or nitrogen-based species ( $\mathrm{X}^{\prime}$ ) to the ascorbate radical (AFR). The AFR can be recycled to ascorbate by microsomal NADH-dependent reductases or 2 molecules of the AFR can dismutate to ascorbate and DHA. The latter can leave the cell on the glucose transporter, or undergo two-electron reduction to ascorbate via GSH or NADPHdependent mechanisms. DHA can also enter the cell on the GLUT-type glucose transport, and then be reduced to ascorbate. 
Ascorbate effects on atherosclerosis

Table 1

\begin{tabular}{|c|c|c|}
\hline Step in atherosclerosis: & Effect of Vitamin C: & References \\
\hline Direct oxidation of LDL & $\begin{array}{l}\text { Prevents } \\
\text { Recycles } \alpha \text {-tocopherol }\end{array}$ & $\begin{array}{l}\text { (Frei et al., 1989; Niki et al., 1995) } \\
\text { (Frei, 1991) }\end{array}$ \\
\hline \multicolumn{3}{|l|}{ Endothelial cell dysfunction } \\
\hline Nitric oxide generation & Enhances & $\begin{array}{l}\text { (Heller et al., 1999; Heller et al., 2001; Huang et al., } \\
2000)\end{array}$ \\
\hline $\begin{array}{l}\text { Type IV collagen synthesis } \\
\text { Endothelial cell proliferation }\end{array}$ & $\begin{array}{l}\text { Stimulates } \\
\text { Stimulates }\end{array}$ & $\begin{array}{l}\text { (Yoshikawa et al., 2001) } \\
\text { (Saeed et al. 2003. Schor et al. 1983) }\end{array}$ \\
\hline Endothelial cell death & Prevents & $\begin{array}{l}\text { (Recchioni et al., 2002; Rossig et al., 2001; Saeed et al., } \\
\text { 2003) }\end{array}$ \\
\hline \multicolumn{3}{|l|}{ VSMC's } \\
\hline Recruitment and proliferation & Inhibits & $\begin{array}{l}\text { (Ivanov et al., 1997; Siow et al., 1998; Ulrich- } \\
\text { Merzenich et al., 2002) }\end{array}$ \\
\hline $\begin{array}{l}\text { Dedifferentiation } \\
\text { Collagen synthesis }\end{array}$ & $\begin{array}{l}\text { Inhibits } \\
\text { Stimulates }\end{array}$ & $\begin{array}{l}\text { (Arakawa et al., 2000; Arakawa et al., 2003) } \\
\text { (Schwartz et al., 1982) }\end{array}$ \\
\hline \multicolumn{3}{|l|}{ Monocyte/macrophages } \\
\hline LDL uptake and modification & Controversial & (Stait \& Leake, 1994) \\
\hline Inflammatory markers & Inhibits & (May et al., 2005b) \\
\hline Nitric oxide release & Inhibits & (Mizutani et al., 1998) \\
\hline
\end{tabular}

